Page $289-312$

\title{
Analisis Pengaruh Kualitas Pelayanan Terhadap Loyalitas Nasabah Baitul Maal wat Tamwil
}

\author{
Rini Dwiyani Hadiwidjaja \\ Fakultas Ekonomi Universitas Terbuka \\ rini@ut.ac.id
}

\begin{abstract}
The aim of this research is to analyze the effect of service quality to customers' loyalty in BMT customers. The method that used in this research is descriptive analysis and multiple regression analysis. The result shows that the service quality in good and high category. But, the customers' loyalty in medium category. To increase the loyalty of the customers, it needs to increase the service quality to the customers. This will had a positive effect on customers loyalti. Customers' loyalty can be a good promotion to the BMT.
\end{abstract}

Key Words: service quality, customers' loyalty, baitul maal wat tamwil

\begin{abstract}
Abstrak
Penelitian ini dilakukan untuk menganalisis pengaruh kualitas terhadap loyalitas pelayanan pada nasabah BMT. Metode analisis data yang digunakan adalah analisis deskritif dan analisis regresi berganda. Hasil penelitian menunjukan bahwa kualitas pelayanan termasuk dalam kategori baik dan tinggi. Namun loyalitas nasabah dalam kategori sedang. Upaya meningkatkan loyalitas nasabah dengan memanfaatkan pelayanan di BMT di Pamulang, pimpinan dan pihak terkait perlu memperhatikan kualitas pelayanan yang diberikan kepada nasabah karena kualitas pelayanan berpengaruh positif dan nyata terhadap loyalitas nasabah. Loyalitas nasabah juga dapat menjadi sarana promosi bagi BMT di Pamulang melalui pemahaman sikap dan perilaku nasabah sebagai pelanggan jasa.
\end{abstract}

Kata Kunci : kualitas pelayanan, loyalitas nasabah, baitul maal wat tamwil

Diterima: 25 April 2017; Revisi: I5 Agustus 2017; Disetujui: 30 Agustus 2017 


\section{PENDAHULUAN}

Baytul Maal wat Tamwil (BMT) merupakan salah satu Lembaga Keuangan Bukan Bank (LKBB) yang sangat dibutuhkan oleh pengusaha kecil di sektor riil, sehingga dengan banyaknya pengusaha-pengusaha kecil menyebabkan pertumbuhan BMT semakin meningkat. Pengembangan LKB/LKBB merupakan kebutuhan yang tidak dapat dihindari, karena penilaian masyarakat terhadap LKB/LKBB tidak hanya terpaku pada masalah kuantitas seperti bunga atau bagi hasil yang diberikan, namun sudah berkembang pada persoalan kualitas, baik itu mengenai produk jasa maupun pelayanannya. Artinya masyarakat sudah makin kritis terhadap LKB/LKBB, hal ini terbukti dengan makin banyaknya protes baik secara langsung, misalnya, pindah sebagai nasabah LKB/LKBB lain dan protes langsung karena permasalahan yang dirasakan tidak memuaskan penyelesaiannya. Kondisi inilah yang menyebabkan perlunya pelayanan yangmemuaskan kepada nasabah dan mutlak dilakukan oleh LKB/LKBB agar masyarakat makin terkesan dengan pelayanan yang semakin baik.

Kualitas pelayanan merupakan salah satu faktor kunci bagi keberhasilan LKB/LKBB sebagai perusahaan jasa karena tidak ada yang lebih penting lagi bagi sebuah LKB/LKBB. Jika pelayanan diberikan kepada nasabah baik dan memuaskan maka akan berpengaruh positif terhadap kinerja usaha, sebaliknya pelayanan yang diberikan kepada nasabah kurang memuaskan akan berpengaruh negatif terhadap kinerja usaha, jadi pelayanan mempunyai andil dan peran terhadap kinerja usaha. Beranjak dari penelitian Marketing Research Specialist, dalam Raksadipoera (1997) tentang kualitas pelayanan dikatakan bahwa lebih dari $65 \%$ pelanggan suatu LKB/LKBB berpindah ke LKB/LKBB pesaing karena alasan service delivery quality, antara lain karena kurang mendapat perhatian sebanyak $20 \%$ dan $45 \%$ karena alasan pelayanan yang tidak ramah.

Berdasarkan pengamatan sementara, tidak optimalnya penyampaian kualitas pelayanan yang diberikan BMT di Tangerang Selatan khususnya Pamulang dapat dilihat dari segi ruang layanan yang kurang nyaman, sistem antrian yang tidak rapi, kecepatan teller dalam menyelesaikan transaksi, sikap pegawai yang kurang simpatik, kurang tanggap dalam memberikan informasi dan pelayanan kepada nasabah dan pemahaman pegawai yang masih kurang tentang kebutuhan nasabah. Masih rendahnya tingkat kemampuan BMT di Tangerang Selatan untuk bersaing dalam industri LKB/LKBB, diduga 
karena dalam pelaksanaan operasionalnya, yang belum sepenuhnya memperhatikan kualitas pelayanan kepada nasabahnya. Tujuan penelitian ini adalah untuk memperoleh data dan informasi mengenai kualitas pelayanan melalui dimensi Tangible, Emphaty, Responsiveness, Reliability dan Assurance serta loyalitas nasabah BMT di Tangerang Selatan khususnya Pamulang serta menguji pengaruh kualitas pelayanan terhadap loyalitas nasabah pada BMT.

Zeithaml (1990) menyebutkan bahwa kualitas pelayanan adalah penyampaian pelayanan secara excellence atau superior dibandingkan dengan harapan konsumen. Dengan demikian, terdapat dua faktor yang mempengaruhi kualitas pelayanan yaitu expected service dan perceived service. Apabila jasa yang diterima sesuai dengan yang diharapkan maka kualitas pelayanan baik atau memuaskan. Akan tetapi jika pelayanan yang diterima melampaui harapan konsumen maka konsumen akan sangat puas dan kualitas pelayanan yang dipersepsikan sangat baik atau ideal. Sebaliknya bila pelayanan yang diterima lebih rendah dari yang diharapkan maka kualitas pelayanan akan dipersepsikan buruk. Oleh karena itu baik tidaknya kualitas pelayanan tergantung pada kemampuan penyedia jasa untuk dapat konsisten memenuhi kebutuhan konsumen. Tjiptono (1996) menyimpulkan bahwa kualitas yang baik bukan berdasarkan sudut pandang penyedia jasa melainkan berdasarkan sudut pandang atau persepsi konsumen karena konsumenlah yang mengkonsumsi dan menikmati jasa perusahaan, sehingga merekalah yang seharusnya membentuk kualitas jasa. Persepsi konsumen terhadap kualitas jasa merupakan penilaian menyeluruh atau keunggulan suatu jasa.

Parasuraman dkk. (dalam Zeithaml dan Bitner, 1996) mengemukakan bahwa ada lima dimensi pokok kualitas pelayanan, diantaranya: (I) tangible, yaitu fasilitas fisik yang ditawarkan kepada konsumen (2) emphaty, yaitu mudah dimengerti, dipahami dan pemantauan terhadap keinginan konsumen (3) responsiveness, yaitu kesiapan dan kecepatan penyedia jasa dalam penyelesaian masalah (4) reliability, yaitu konsistensi dari penampilan pelayanan dan keandalan pelayanan dan (5) assurance, yaitu kemampuan, ketrampilan, keramahan, kepercayaan dan keamanan dari petugas. Penelitian ini menggunakan pendekatan tersebut untuk mengukur kualitas pelayanan yang diberikan BMT Di Pamulang. 
Konsumen yang loyal memiliki karakteristik sebagai berikut: (I) melakukan pembelian secara teratur, (2) membeli di luar lini produk atau jasa (3) menolak produk lain (4) menunjukkan kekebalan dari tarikan persaingan (Griffin, 1996). Untuk menjadi konsumen yang loyal maka seorang konsumen harus melalui beberapa tahapan, diantaranya : (I) suspects yaitu mencakup semua orang yang akan membeli barang/jasa perusahaan, pada tahap ini konsumen akan membeli tetapi belum mengetahui mengenai perusahaan dan barang atau jasa yang ditawarkan; (2) prospects yaitu orang yang memiliki kebutuhan atau jasa tertentu dan mempunyai kemampuan untuk membelinya, pada tahap ini konsumen belum melakukan pembelian tetapi telah mengetahui keberadaan perusahaan dan barang atau jasa yang ditawarkan; (3) disqualified prospects yaitu orang telah mengetahui keberadaan barang dan jasa tertentu tetapi tidak mempunyai kebutuhan akan barang/jasa tersebut dan tidak punya kemampuan untuk membeli; (4) first time customers yaitu konsumen yang membeli untuk pertama kalinya; (5) repeat customers yaitu konsumen yang telah melakukan pembelian suatu produk/jasa dua kali atau lebih; (6) clients yaitu membeli semua barang/jasa yang ditawarkan yang mereka butuhkan dan konsumen telah melakukan pembelian secara teratur; dan (7) advocates yaitu konsumen telah membeli semua barang atau jasa yang ditawarkan secara teratur dan mendorong teman-teman yang lain untuk melakukan pembelian (Griffin, 1996). Menurut Oliver (1997) ada empat tahap loyalitas diantaranya: (I) cognitive loyality, (2) affective loyality, (3) conative loyality, dan (4) action loyality.

\section{METODE}

Bentuk penelitian ini yaitu penelitian verifikatif yang dilaksanakan melalui metode survei pada nasabah BMT di wilayah sekitar Pamulang. Jenis datanya adalah data primer dan data sekunder. Data primer berupa himpunan informasi yang diperoleh dalam survei dengan wawancara dan menggunakan kuesioner terstruktur yang diberikan kepada nasabah yang menjadi responden terpilih. Data sekunder didapat dengan menelaah data yang diperoleh dari BMT, mempelajari dokumen-dokumen instansi terkait, laporan penelitian, publikasi, dan literatur lain yang mendukung penelitian.

Variabel independen penelitian ini adalah kualitas pelayanan yang terdiri dari lima dimensi yaitu Tangible, Emphaty, Responsiveness, Reliability Dan Assurance, sedangkan 
variabel dependennya adalah loyalitas nasabah. Kemudian variabel kualitas pelayanan dijabarkan lagi menjadi sejumlah sub variabel lengkap dengan konsep, indikator, satuan pengukuran, dan skala pengukurannya. Populasi penelitian ini adalah seluruh nasabah BMT-BMT di Tangerang Selatan. Teknik penarikan sampel yang digunakan adalah Simple Random Sampling yang alokasinya sembarang, dan diperoleh sampel nasabah BMT di wilayah Pamulang berjumlah 120 orang. Metode analisis yang digunakan adalah analisis deskriptif dan analisis regresi. Analisis deskriptif digunakan untuk mengetahui tingkat kualitas pelayanan, dan loyalitas nasabah BMT.

\section{Tabel I.}

Kriteria Penilaian Tingkat Kualitas Pelayanan, dan Loyalitas Nasabah BMT

\section{Variabel} Jumlah Skor Tertinggi Terendah Jumlah Klasifikasi

Tangible

Emphaty

Responsiveness $\quad 3000$

Reliability
1200

3000

600

600

3600

\section{Rentang}

Pengklasifikasi

\section{Kriteria}

1200 - 2160 Sangat rendah

2161-3120 Rendah

3|2| - 4080 Sedang

408I - 5040 Tinggi

504I - 6000 Sangat tinggi

600 - 1080 Sangat rendah

I08I - I560 Rendah

|56| - 2040 Sedang

204I - 2520 Tinggi

2521 - 3000 Sangat tinggi

$600-1080$ Sangat rendah

108I - I560 Rendah

|56| - 2040 Sedang

204I - 2520 Tinggi

2521 - 3000 Sangat tinggi

720 - 1296 Sangat rendah

| 297 - 1872 Rendah

1873 - 2448 Sedang

2449 - 3024 Tinggi

3025 - 3600 Sangat tinggi 


\begin{tabular}{|c|c|c|c|c|c|}
\hline \multirow{2}{*}{ Variabel } & \multicolumn{2}{|c|}{ Jumlah Skor } & \multirow{2}{*}{$\begin{array}{c}\text { Jumlah } \\
\text { Klasifikasi }\end{array}$} & \multirow{2}{*}{$\begin{array}{c}\text { Rentang } \\
\text { Pengklasifikasi }\end{array}$} & \multirow{2}{*}{ Kriteria } \\
\hline & Tertinggi & Terendah & & & \\
\hline \multirow{5}{*}{ Assurance } & & & & $600-1080$ & Sangat rendah \\
\hline & & & & $1081-1560$ & Rendah \\
\hline & 3000 & 600 & 5 & $|56|-2040$ & Sedang \\
\hline & & & & $204 I-2520$ & Tinggi \\
\hline & & & & $2521-3000$ & Sangat tinggi \\
\hline & & & & $0-20$ & Sangat rendah \\
\hline Kepuasan & & & & $21-40$ & Rendah \\
\hline \multirow{2}{*}{ Pelanggan } & 100 & 0 & 5 & $4 I-60$ & Sedang \\
\hline & & & & $61-80$ & Tinggi \\
\hline \multirow{6}{*}{ Loyalitas } & & & & $81-100$ & Sangat tinggi \\
\hline & & & & $480-864$ & Sangat rendah \\
\hline & 2400 & 480 & 5 & $865-1248$ & Rendah \\
\hline & & & & $1249-1632$ & Sedang \\
\hline & & & & $1633-2016$ & Tinggi \\
\hline & & & & $2017-2400$ & Sangat tinggi \\
\hline
\end{tabular}

Sumber : Hasil olah data

Untuk mengetahui tingkat kualitas pelayanan, dan loyalitas nasabah berada dalam kategori : sangat tinggi, tinggi, sedang, rendah dan sangat rendah maka dibuat kriteria pengklasifikasian yang mengacu pada ketentuan yang dikemukakan oleh Arikunto (1996) dan Umar (2000) yang rentangan skor dari dimensi kualitas pelayanan, nilai pelayanan, dan loyalitas tersebut dicari dengan rumus sebagai berikut:

\section{Skor tertinggi - Skor terendah}

Rentang skor $=$ Jumlah klasifikasi

Dimana :

Skor tertinggi : jumlah responden $\mathrm{x}$ bobot tertinggi $\mathrm{x}$ jumlah item

Skor terendah : jumlah responden $\mathrm{x}$ bobot terendah $\mathrm{x}$ jumlah item

Berdasarkan pedoman ini maka kriteria pengklasifikasian data mengenai variabel kualitas pelayanan dan loyalitas nasabah pada BMT dapat dilihat pada Tabel I. Analisis regresi digunakan untuk mengetahui besarnya hubungan dan pengaruh dari dimensi Tangible, Emphaty, Responsiveness, Reliability Dan Assurance sebagai 
kualitas pelayanan erhadap loyalitas nasabah BMT di wilayah sekitar Pamulang.

\section{HASIL DAN PEMBAHASAN}

Dalam penelitian ini untuk mengukur kualitas pelayanan pada BMT digunakan lima dimensi, (a) tangible yaitu fasilitas fisik yang meliputi : kondisi fisik, perlengkapan, dan kondisi SDM; (b) emphaty yaitu kemudahan menghubungi, kejelasan dalam berkomunikasi dan pengertian terhadap nasabah; (c) responsiveness yaitu kesediaan, kesiapan dan kecepatan petugas BMT dalam memberikan pelayanan; (d) reliability yaitu ketepatan dan kesesuaian sistem pelayanan BMT dengan standar yang telah ditentukan; dan (e) assurance yaitu penampilan/ kemampuan/pengetahuan yang memadai, sikap yang sopan dan bersahabat, dan jaminan bebas dari resiko dan bahaya dari BMT. Kualitas pelayanan ditentukan dengan membandingkan antara pelayanan yang dirasakan (perceived service) dengan harapan (expectation).

\section{Tabel 2. Kualitas Pelayanan Pada BMT}

\begin{tabular}{lcc}
\hline \multicolumn{1}{c}{ Dimensi Kualitas } & Skor Kualitas Pelayanan & Kategori Kualitas \\
\hline Tangible & 4382 & Tinggi \\
Emphaty & 2183 & Tinggi \\
Responsiveness & 2142 & Tinggi \\
Reliability & 2552 & Tinggi \\
Assurance & 2358 & Tinggi \\
Total & 13923 & Tinggi \\
\hline
\end{tabular}

Sumber : Hasil olah data

Hasil scoring pada Tabel 2 dapat ditunjukkan bahwa kualitas pelayanan BMT baik secara total maupun per dimensi kualitas pelayanan berada pada kategori tinggi. Hal ini menunjukkan bahwa BMT dalam memberikan pelayanan kepada nasabahnya sudah memperhatikan aspek-aspek kualitas pelayanan dengan baik, namun demikian BMT masih perlu untuk meningkatkan kualitas pelayanannya agar dapat mencapai kategori yang "sangat tinggi".

Kinerja yang dirasakan nasabah terhadap kualitas pelayanan pada BMT dapat dikelompokkan dalam lima dimensi kualitas pelayanan, yaitu kinerja yang dirasakan 
nasabah terhadap dimensi : (1) tangible (2) emphaty; (3) responsiveness; (4) reliability; dan (5) assurance.

Kinerja yang dirasakan nasabah pada dimensi Tangible dapat ditunjukkan melalui tampilan fisik gedung, perlengkapan dan Sumber Daya Manusia (SDM). Tampilan Fisik Gedung BMT, yaitu: (a) Kestrategisan lokasi gedung, sebagian besar nasabah memberikan respon terhadap kinerja tampilan fisik gedung BMT khususnya pada lokasi gedung dirasakan "strategis" sebesar 36\%; (b) Luas gedung, hampir sebagian besar nasabah memberikan respon terhadap kinerja tampilan fisik gedung BMT khususnya pada luas lahan gedung dirasakan "luas" dari 120 nasabah yang menyatakan "luas" 50 nasabah atau 42\%; (c) Ruang Pelayanan, Tempat Parkir, Mushola, Ruang Tunggu, Ruang Terbuka dan WC bagi sebagian besar nasabah dirasakan "memadai"; (d) Kenyamanan dan Kebersihan Tempat Pelayanan bagi sebagian besar nasabah BMT dirasakan "nyaman dan bersih" (40\%) karena kondisi gedung dan tempat pelayanan cukup sejuk dan menyenangkan, namun masih ada sekitar 5\% responden merasakan bahwa kondisi gedung dan tampat pelayanan "tidak nyaman dan bersih" .

Tampilan Fisik Perlengkapan BMT: (a) Kelengkapan Sarana Pelayanan bagi sebagian besar nasabah BMT dirasakan "lengkap" yaitu sebesar 44\% atau 53 nasabah, namun masih ada sekitar II\% nasabah merasakan bahwa kelengkapan sarana pelayanan dirasakan "tidak lengkap"; (b) Ketersediaan Buku-Buku Petunjuk bagi nasabah BMT di Pamulang dirasakan "tersedia" yaitu sebesar 43\%, namun masih ada sekitar $16 \%$ responden merasakan bahwa ketersediaan buku-buku petunjuk dirasakan "tidak tersedia"; (c) Kelengkapan Sarana Administrasi bagi sebagian besar nasabah BMT dirasakan "cukup lengkap" yaitu 57 nasabah atau 48\%, karena BMT di Pamulang dalam memberikan pelayanan transaksi kepada nasabah selalu mengadakan pengadministrasian yang rapi, lengkap, teliti, dan akurat agar dapat meminimisasi kesalahan atau pengertian antara pihak nasabah dengan pihak bank. Namun masih ada sekitar $6 \%$ responden yang masih merasakan "tidak lengkap".

Tampilan Fisik Sumber Daya Manusia (SDM) BMT: (a) Kesiapan Pegawai dalam Melayani Nasabah, sebagian besar nasabah merasakan kesiapan pegawai dalam melayani nasabah BMT di Pamulang "Siap" (43\%) karena staf pegawai BMT pada umumnya sedah memiliki pengetahuan dan keterampilan yang cukup memadai dalam memberikan pelayanan kepada nasabah, namun masih ada sekitar 3\% dari nasabah yang merasakan 
bahwa pegawai BMT dalam memberikan pelayanan kepada nasabah "tidak siap" karena masih ada beberapa pegawai yang belum memahami pentingnya pelayanan dalam industri perbankan; (b) Penampilan dan Kerapihan Front Office bagi sebagian nasabah dirasakan dirasakan "ramah dan rapi" (46\% atau 55 nasabah) karena petugas front office BMT telah diberikan bekal yang cukup matang mengenai manajemen pelayanan bank dan sopan santun dalam berbusana.

Kinerja yang dirasakan nasabah terhadap dimensi kualitas pelayanan emphaty dapat ditunjukkan melalui pertanyaan sebagai berikut: (a) Kemudahan dalam Menghubungi Petugas, Pimpinan, dan Staf BMT, kemudahan menghubungi pegawai yang bertugas di BMT di Pamulang dirasakan nasabah "cukup mudah" (53\% atau 63 nasabah) karena pegawai BMT umumnya sudah menyadari bahwa para nasabah akan menjadi pelanggan yang setia apabila mereka mendapat kemudahan untuk menghubungi pegawai baik dalam memperoleh pelayanan maupun dalam menyampaikan keluhan-keluhan yang dihadapi nasabah. Namun masih ada sekitar 5\% dari nasabah yang merasa "tidak mudah" dalam menghubungi pegawai BMT karena pegawai terlalu sibuk, kurang memberikan perhatian secara individu, dan kurang ramah dalam berkomunikasi. Kemudahan dalam menghubungi pimpinan dan staf BMT dirasakan "cukup mudah" karena pimpinan dan staf pegawai BMT umumnya orang yang tekun dalam bidang jasa perbankan dan memberikan pelayanan yang terbaik kepada nasabahnya agar betul-betul menjadi partner yang baik; (b) Kesungguhan Teller dalam Memberi Pelayanan Secara Individu, hasil olah data menunjukkan bahwa nasabah merasakan bahwa kesungguhan teller dalam memberi perhatian secara individu "cukup bersungguh-sungguh" (41\%) karena petugas teller menyadari peranan dan fungsinya dengan baik, namun masih ada sekitar $5 \%$ dari nasabah yang merasakan bahwa perhatian teller secara individu "tidak bersungguh-sungguh" karena masih ada sebagian kecil dari petugas memiliki sifat egois dan apatis terhadap nasabah; (c) Kemampuan Pegawai Untuk Memahami Setiap Kebutuhan Nasabah, nasabah merasakan bahwa kemampuan pegawai bank untuk memahami setiap kebutuhan "mampu" (43\%) karena pegawai telah mendapatkan pendidikan dan pelatihan yang profesional sebelum mereka ditugaskan di lapangan. Kemampuan pegawai untuk mengenal setiap nasabah dirasakan "cukup mampu" (5l\%) karena sebagian nasabah merasa kenal baik dengan para pegawai BMT. 
Kinerja yang dirasakan nasabah terhadap dimensi responsiveness dapat ditunjukkan dalam pertanyaan sebagai berikut. (a) Kesiapan dan Kesediaan Pegawai Untuk Melayani Nasabah, sebagian besar nasabah merasakan bahwa kesediaan dan kesiapan pegawai untuk melayani nasabah BMT di Pamulang dirasakan "bersedia dan siap" (40\%) karena pegawai BMT pada umumnya sudah mempunyai kesadaran yang relatif tinggi dan menyadari bahwa para nasabah akan menjadi pelanggan yang setia apabila pegawai memiliki kesediaan dan kesiapan dalam melayani nasabah, namun masih ada pegawai BMT yang "tidak bersedia dan siap" dalam melayani nasabah; (b) Kecepatan dan Ketepatan Pegawai Dalam Melayani Nasabah dan Pengiriman Slip.

Transaksi yang Dilakukan Karyawan yang dirasakan oleh nasabah "cepat dan tepat" (4l\%) karena pegawai BMT di Pamulang pada umumnya mempunyai pengalaman kerja di bidang jasa perbankan, namun masih ada nasabah yang merasa pelayanan yang diberikan para pegawai "tidak cepat dan tepat" karena peralatan otomatis dalam pelayanan masih sangat terbatas; sedangkan kecepatan dan ketepatan pengiriman slip transaksi dirasakan oleh nasabah "cepat dan tepat" (45\%); (c) Kesediaan dan Ketanggapan Customer Service Officer Dalam Memberi Layanan Pada Nasabah, hasil olah data menunjukkan bahwa sebagian besar nasabah merasakan bahwa kesediaan dan ketanggapan customer service officer dalam memberikan layanan pada nasabah di BMT di Pamulang "bersedia dan cepat" (42\%); (d) Kesediaan dan Kecepatan Pimpinan Dalam Menangani Keluhan dan Kebutuhan Nasabah, bagi sebagian besar nasabah diraskan "bersedia dan cepat" (5I\%) karena posisi pimpinan pada BMT di Pamulang umumnya ditempati oleh pegawai-pegawai yang berpengalaman dibidang jasa, namun masih ada sekitar $12 \%$ dari nasabah yang merasa bahwa pimpinan "tidak bersedia dan cepat" terhadap keluhan nasabah karena pimpinan masih sangat sibuk untuk menangani hal-hal lain dari BMT yang bersifat eksternal.

Kinerja yang dirasakan nasabah terhadap dimensi kualitas pelayanan reliability dapat ditunjukkan sebagai berikut. (a) Kesesuaian dan Ketepatan Pemenuhan Janji Pegawai Kepada Nasabah, Pelayanan Teller Dalam Menyelesaikan Transaksi, dan Aturan Pelayanan; (b) (a) kesesuaian dan ketepatan pemenuhan janjijanji pegawai kepada nasabah dirasakan "sesuai dan tepat" (43\%) karena hal ini 
akan membuat nasabah lebih percaya dan meningkatkan loyalitas mereka pada BMT; (b) kesesuaian dan kecepatan pelayanan teller dalam menyelesaikan transaksi yang dilakukan oleh nasabah adalah "sesuai dan tepat" (44\%) karena pegawai teller pada BMT di Pamulang pada umumnya mempunyai keterampilan yang memadai; (c) kesesuaian dan ketepatan aturan pelayanan yang diberikan oleh BMT di Pamulang kepada nasabah dirasakan "sesuai dan tepat" (44\%). Ada 9\% dari responden mengatakan bahwa pelayanan yang diberikan oleh BMT "tidak sesuai dan tepat" dengan aturan yang berlaku karena masih ada beberapa pegawai dalam memberikan pelayanan kepada nasabah mengabaikan aturan yang berlaku dan dalam memberi pelayanan lebih mengutamakan orang yang dikenal dekat tanpa melihat sistem antrian yang berlaku; (c) Kemampuan Dalam Menjamin Keamanan Uang Nasabah pada sebagian besar nasabah dirasakan "terjamin" karena sampai saat ini BMT selalu menjaga dan merahasiakan uang nasabah sesuai dengan aturan yang berlaku; (d) Keterlibatan Pegawai Dalam Pelaksanaan Pelayanan, hasil olah data menunjukkan bahwa nasabah merasakan "terlibat" (39\%), namun masih ada sekitar II\% dari responden yang merasakan bahwa pegawai dalam memberikan pelayanan "tidak terlibat" karena ada beberapa aspek pelayanan atau produk yang ditawarkan oleh BMT bisa dilakukan sendiri pelayanannya oleh nasabah; (e) Relevansi Pelayanan yang Diberikan Dengan Kebutuhan Nasabah, hasil olah data menunjukkan bahwa pada sebagian besar nasabah dirasakan "relevan" (38\%). Namun masih ada sekitar 13\% responden yang merasakan relevansi pelayanan yang diberikan dengan kebutuhan nasabah dirasakan "tidak relevan".

Kinerja yang dirasakan oleh nasabah terhadap dimensi kualitas pelayanan assurance dapat ditunjukkan sebagai berikut: (a) Pengetahuan dan Kemampuan Teller Dalam Menangani Transasksi, sebagian besar nasabah merasakan pengetahuan dan kemampuan teller dalam menangani transaksi yang dilakukan nasabah di BMT dirasakan "tahu dan mampu" (38\%) karena petugas teller pada BMT umumnya pegawai yang jujur, cermat, dam dapat dipercaya oleh pihak bank; (b) Cara Teller Dalam Menjamin Kepastian dan Keamanan Dana Nasabah, sebagian besar nasabah merasakan teller dalam menjamin kepastian dan keamanan dana nasabah yang disimpan di BMT dirasakan "terjamin" (57\% atau 68 nasabah) karena petugas teller sudah mencatat dan mengecek kebenaran dan sahnya bukti-bukti transaksi yang dilakukan pihak BMT 
kepada nasabah sehingga dapat dipertanggungjawabkan secara formal; (c) Keramahan Pegawai Dalam Memberikan Pelayanan Kepada Nasabah, sebagian besar nasabah merasakan keramahan pegawai dalam memberikan pelayanan kepada nasabah di BMT dirasakan "ramah" (45\%) kemudian "sangat ramah" (33\%) dan "cukup ramah" (23\%) karena para pegawai yang memberikan pelayanan kepada nasabah umumnya para pegawai yang terdidik dan terlatih; (d) Keterampilan Pegawai Dalam Bekerja dan Memberi Pelayanan Kepada Nasabah, sebagian besar nasabah merasakan keterampilan pegawai dalam bekerja dan memberi pelayanan kepada nasabah dirasakan "terampil" (48\%), “cukup terampil” (36\%) dan "sangat terampil” (I3\%) karena pegawai BMT cukup profesional baik dalam memberi pelayanan maupun dalam menangani komplain nasabah; (e) Kejujuran dan Keterbukaan Pimpinan Dalam Memberi Informasi dan Pelayanan Kepada Nasabah, sebagian besar nasabah merasakan bahwa kejujuran dan keterbukaan pimpinan dalam memberi informasi dan pelayanan kepada nasabah "jujur dan terbuka" karena pimpinan pada BMT pada umumnya diduduki oleh orang-orang yang berpengalaman, ahli dalam bidangnya, dan profesional.

Tabel 3. Harapan Nasabah Terhadaq Tampilan Fisik Gedunq BMT

\begin{tabular}{|c|c|c|c|c|c|c|c|c|c|c|c|c|}
\hline \multirow{2}{*}{$\begin{array}{l}\begin{array}{c}\text { Tanggapan } \\
\text { Nasabah }\end{array} \\
\text { Pertanyaan }\end{array}$} & \multicolumn{2}{|c|}{$\begin{array}{l}\text { Sangat } \\
\text { Penting }\end{array}$} & \multicolumn{2}{|c|}{ Penting } & \multicolumn{2}{|c|}{$\begin{array}{l}\text { Cukup } \\
\text { Penting }\end{array}$} & \multicolumn{2}{|c|}{$\begin{array}{l}\text { Kurang } \\
\text { Penting }\end{array}$} & \multicolumn{2}{|c|}{$\begin{array}{l}\text { Sangat } \\
\text { Kurang } \\
\text { Penting }\end{array}$} & \multicolumn{2}{|c|}{ Jumlah } \\
\hline & f & $\%$ & $f$ & $\%$ & $f$ & $\%$ & $f$ & $\%$ & $f$ & $\%$ & $f$ & $\%$ \\
\hline Lokasi gedung & 101 & 84 & 19 & 16 & 0 & 0 & 0 & 0 & 0 & 0 & 120 & 100 \\
\hline Luas lahan gedung & 50 & 42 & 62 & 52 & 8 & 7 & 0 & 0 & 0 & 0 & 120 & 100 \\
\hline Ruang pelayanan & 43 & 36 & 68 & 57 & 8 & 7 & 1 & I & 0 & 0 & 120 & 100 \\
\hline $\begin{array}{l}\text { Tempat parkir, mushola, } \\
\text { ruang tunggu, ruang } \\
\text { terbuka dan WC }\end{array}$ & 55 & 46 & 53 & 44 & 12 & 10 & 0 & 0 & 0 & 0 & 120 & 100 \\
\hline $\begin{array}{l}\text { Kenyamanan, kebersihan } \\
\text { BMT dan tempat pelayanan }\end{array}$ & 63 & 53 & 55 & 46 & 2 & 2 & 0 & 0 & 0 & 0 & 120 & 100 \\
\hline
\end{tabular}

Sumber : hasil olah data

Tingkat harapan nasabah dalam hal ini identik dengan tingkat kepentingan nasabah. Nasabah yang memiliki tingkat kepentingan tinggi berarti memiliki harapan yang besar terhadap kualitas pelayanan yang ditawarkan oleh BMT di Pamulang. Berikut ini akan diuraikan tentang harapan/kepentingan nasabah tentang kelima dimensi kualitas pelayanan yang ditawarkan oleh BMT di Pamulang, yang meliputi dimensi : (I) tangible (2) emphaty; (3) responsiveness; (4) reliability; dan (5) assurance. 
Harapan nasabah terhadap dimensi Tangible dapat ditunjukkan melalui tampilan fisik gedung, perlengkapan dan Sumber Daya Manusia (SDM). Pada Tabel 3 menunjukkan bahwa sebagian besar responden menaruh harapan yang besar pada tampilan fisik berupa gedung BMT di Pamulang terhadap lokasi gedung dan kenyamanan serta kebersihan tempat pelayanan. Aspek-aspek lainnya secara umum dianggap penting oleh nasabah. Penilaian terhadap tampilan fisik memberikan keyakinan dan persepsi nasabah bahwa jasa yang diberikan akan sesuai dengan kenyataan yang mereka lihat pertama kali.

Tabel 4. Harapan Nasabah Terhadap Tampilan Fisik Perlengkapan BMT

\begin{tabular}{|c|c|c|c|c|c|c|c|c|c|c|c|c|}
\hline \multirow{2}{*}{$\begin{array}{c}\begin{array}{c}\text { Tanggapan } \\
\text { Nasabah }\end{array} \\
\text { Pertanyaan }\end{array}$} & \multicolumn{2}{|c|}{$\begin{array}{l}\text { Sangat } \\
\text { Penting }\end{array}$} & \multicolumn{2}{|c|}{ Penting } & \multicolumn{2}{|c|}{$\begin{array}{l}\text { Cukup } \\
\text { Penting }\end{array}$} & \multicolumn{2}{|c|}{$\begin{array}{l}\text { Kurang } \\
\text { Penting }\end{array}$} & \multicolumn{2}{|c|}{$\begin{array}{l}\text { Sangat } \\
\text { Kurang } \\
\text { Penting }\end{array}$} & \multicolumn{2}{|c|}{ Jumlah } \\
\hline & $f$ & $\%$ & f & $\%$ & $f$ & $\%$ & $f$ & $\%$ & $f$ & $\%$ & $f$ & $\%$ \\
\hline Sarana Pelayanan & 65 & 54 & 47 & 39 & 8 & 7 & 0 & 0 & 0 & 0 & 120 & 100 \\
\hline $\begin{array}{l}\text { Ketersediaan } \\
\text { buku-buku } \\
\text { petunjuk } \\
\text { pelayanan nasabah }\end{array}$ & 43 & 36 & 56 & 47 & 18 & 15 & 3 & 3 & 0 & 0 & 120 & 100 \\
\hline $\begin{array}{l}\text { Kelengkapan } \\
\text { sarana }\end{array}$ & 52 & 43 & 58 & 48 & 10 & 8 & 0 & 0 & 0 & 0 & 120 & 100 \\
\hline
\end{tabular}

Sumber : hasil olah data

Pada Tabel 4 menunjukkan bahwa harapan nasabah dalam aspek ini tercermin pada jawaban responden terhadap "kelengkapan sarana pelayanan". Sarana pelayanan yang lengkap akan berdampak pada kualitas layanan dan harapan nasabah akan memperoleh layanan karena sarana yang lengkap.

Tabel 5. Harapan Nasabah Terhadap Tampilan Fisik SDM BMT

\begin{tabular}{|c|c|c|c|c|c|c|c|c|c|c|c|c|}
\hline \multirow{2}{*}{$\begin{array}{l}\begin{array}{c}\text { Tanggapan } \\
\text { Nasabah }\end{array} \\
\text { Pertanyaan }\end{array}$} & \multicolumn{2}{|c|}{$\begin{array}{l}\text { Sangat } \\
\text { Penting }\end{array}$} & \multicolumn{2}{|c|}{ Penting } & \multicolumn{2}{|c|}{$\begin{array}{l}\text { Cukup } \\
\text { Penting }\end{array}$} & \multicolumn{2}{|c|}{$\begin{array}{l}\text { Kurang } \\
\text { Penting }\end{array}$} & \multicolumn{2}{|c|}{$\begin{array}{l}\text { Sangat } \\
\text { Kurang } \\
\text { Penting } \\
\end{array}$} & \multicolumn{2}{|c|}{ Jumlah } \\
\hline & $f$ & $\%$ & f & $\%$ & $f$ & $\%$ & f & $\%$ & $\mathbf{f}$ & $\%$ & f & $\%$ \\
\hline $\begin{array}{l}\text { Tingkat kesiapan pegawai } \\
\text { Melayani nasabah }\end{array}$ & 83 & 69 & 34 & 28 & 3 & 3 & 0 & 0 & 0 & 0 & 120 & 100 \\
\hline $\begin{array}{l}\text { Penampilan dan kerapihan } \\
\text { pegawai front office }\end{array}$ & 50 & 42 & 59 & 49 & II & 9 & 0 & 0 & 0 & 0 & 120 & 100 \\
\hline
\end{tabular}


Pada Tabel 5 menunjukkan bahwa sebagian besar nasabah menaruh harapan yang besar pada tampilan fisik SDM BMT di Pamulang terhadap tingkat kesiapan pegawai melayani nasabah. Pada Tabel 6 tampak bahwa harapan responden terhadap kualitas pelayanan pada dimensi emphaty. Pada Tabel 6 menunjukkan bahwa sebagian besar nasabah menaruh harapan yang besar dan dianggap sangat penting pada aspek kemudahan menghubungi pegawai yang bertugas di BMT. Sedangkan aspek-aspek yang lainnya secara umum dianggap penting oleh nasabah.

Tabel 6. Harapan Nasabah Terhadap Emphaty

\begin{tabular}{|c|c|c|c|c|c|c|c|c|c|c|c|c|}
\hline $\begin{array}{l}\text { Tanggapan } \\
\text { Nasabah }\end{array}$ & $\begin{array}{l}\text { Sa } \\
\text { Per }\end{array}$ & & Pen & ing & $\begin{array}{l}\text { Cu } \\
\text { Pen }\end{array}$ & & & $\begin{array}{l}\text { ang } \\
\text { ting }\end{array}$ & & & Jum & lah \\
\hline $\begin{array}{l}\text { Pertanyaan } \\
\text { Kemudahan }\end{array}$ & $f$ & $\%$ & $f$ & $\%$ & $f$ & $\%$ & $f$ & $\%$ & $f$ & $\%$ & $f$ & $\%$ \\
\hline menghubungi pegawai & 64 & 53 & 46 & 38 & 10 & 8 & 0 & 0 & 0 & 0 & 120 & 100 \\
\hline $\begin{array}{l}\text { Kemudahan menghubungi } \\
\text { pimpinan dan staf }\end{array}$ & 57 & 48 & 46 & 38 & 14 & 12 & 3 & 2.5 & 0 & 0 & 120 & 100 \\
\hline $\begin{array}{l}\text { Kesungguhan teller dalam } \\
\text { memberikan perhatian }\end{array}$ & 57 & 48 & 49 & 41 & 14 & 12 & 0 & 0 & 0 & 0 & 120 & 100 \\
\hline $\begin{array}{l}\text { Kêmampindivind, } \\
\text { untuk memahama pegai Bank } \\
\text { kebutuhan nasabah }\end{array}$ & 58 & 48 & 49 & 41 & 8 & 7 & 5 & 4 & 0 & 0 & 120 & 100 \\
\hline $\begin{array}{l}\text { Kemampuan pegawai } \\
\text { dalam mengenal setiap } \\
\text { nasabahnya }\end{array}$ & 44 & 37 & 52 & 43 & 21 & 18 & 3 & 3 & 0 & 0 & 120 & 100 \\
\hline
\end{tabular}

Sumber : hasil olah data

Pada Tabel 7 terlihat harapan nasabah terhadap kualitas pelayanan pada dimensi reponsiveness adalah sebagai berikut. Pada Tabel 7 menunjukkan bahwa sebagian besar nasabah menaruh harapan yang besar pada aspek kesediaan dan kesiapan pegawai untuk melayani nasabah. Kecepatan dan ketepatan pegawai dalam mengirim slip transaksi serta kesediaan dan ketanggapan customer service officer dalam memberi pelayanan kepada nasabah juga menjadi harapan besar nasabah. Penilaian yang diberikan kepada aspek responsiveness ini akan mempengaruhi nasabah untuk 
memanfaatkan kembali pelayanan yang ditawarkan oleh BMT di Pamulang.

Pada Tabel 8 menunjukkan bahwa sebagian besar nasabah menaruh harapan yang besar pada aspek kesesuaian dan ketepatan pelayanan teller dalam menyelesaikan transaksi yang dilakukan oleh nasabah, dan kesesuaian dan ketepatan kemampuan BMT dalam menjamin keamanan uang nasabah. Sedangkan aspek yang lainnya dianggap penting dan cukup penting oleh nasabah. Penilaian yang diberikan kepada aspek kualitas pelayanan reliability ini akan mempengaruhi nasabah untuk memanfaatkan kembali pelayanan yang ditawarkan oleh BMT di Pamulang.

Tabel 7. Harapan Nasabah Terhadap Responsiveness

\begin{tabular}{|c|c|c|c|c|c|c|c|c|c|c|c|c|}
\hline \multirow{2}{*}{$\begin{array}{l}\text { Tanggapan Nasabah } \\
\text { Pertanyaan }\end{array}$} & \multicolumn{2}{|c|}{$\begin{array}{l}\text { Sangat } \\
\text { Penting }\end{array}$} & \multicolumn{2}{|c|}{ Penting } & \multicolumn{2}{|c|}{$\begin{array}{l}\text { Cukup } \\
\text { Penting }\end{array}$} & \multicolumn{2}{|c|}{$\begin{array}{l}\text { Kurang } \\
\text { Penting }\end{array}$} & \multicolumn{2}{|c|}{$\begin{array}{l}\text { Sangat } \\
\text { Kurang } \\
\text { Penting }\end{array}$} & \multicolumn{2}{|c|}{ Jumlah } \\
\hline & $f$ & $\%$ & $f$ & $\%$ & $f$ & $\%$ & $f$ & $\%$ & $f$ & $\%$ & $f$ & $\%$ \\
\hline $\begin{array}{l}\text { pegawai untuk melayani } \\
\text { nasabah }\end{array}$ & 81 & 68 & 35 & 29 & 4 & 3 & 0 & 0 & 0 & 0 & 120 & 100 \\
\hline $\begin{array}{l}\text { Kecepatan dan ketepatan } \\
\text { pegawai dalam melayani } \\
\text { nasabah }\end{array}$ & 53 & 44 & 64 & 53 & 3 & 3 & 0 & 0 & 0 & 0 & 120 & 100 \\
\hline $\begin{array}{l}\text { Kecepatan dan ketepatan } \\
\text { pegawai dalam mengirim slip } \\
\text { transaksi yang dilakukan } \\
\text { oleh karyawan bank }\end{array}$ & 63 & 53 & 52 & 43 & 5 & 4 & 0 & 0 & 0 & 0 & 120 & 100 \\
\hline $\begin{array}{l}\text { Kesediaan dan ketanggapan } \\
\text { customer service officer } \\
\text { dalam memberi pelayanan } \\
\text { kepada nasabah }\end{array}$ & 64 & 53 & 38 & 32 & 18 & 15 & 0 & 0 & 0 & 0 & 120 & 100 \\
\hline $\begin{array}{l}\text { Kesediaan dan kecepatan } \\
\text { pimpinan dalam menangani } \\
\text { keluhan dan kebutuhan }\end{array}$ & 46 & 38 & 49 & $4 I$ & 12 & 10 & 13 & II & 0 & 0 & 120 & 100 \\
\hline
\end{tabular}

Sumber : hasil olah data

Pada Tabel 9 menunjukkan bahwa sebagian besar nasabah menaruh harapan yang besar pada aspek pengetahuan dan kemampuan teller dalam menangani transaksi yang dilakukan oleh nasabah, cara teller dalam menjamin kepastian dan rasa aman nasabah atas uang yang disimpan, keramahan pegawai BMT dalam memberikan pelayanan, keterampilan pegawai dalam bekerja dan menyelesaikan tugas 
pemberian pelayanan, dan kejujuran dan keterbukaan pimpinan dalam memberi informasi dan pelayanan.

Pengukuran tingkat kepuasan nasabah terhadap kinerja pelayanan yang ditawarkan oleh BMT di Pamulang, dilakukan dengan cara menentukan perbandingan data ordinal antara kinerja pelayanan yang diterima oleh nasabah dengan kualitas yang diharapkan oleh nasabah. Kepuasan nasabah terhadap pelayanan yang diberikan oleh BMT di Pamulang secara rinci dapat dilihat pada masing-masing dimensi kualitas pelayanan seperti yang tertera pada Tabel I0 sampai dengan Tabel I6.

Tabel 8.

Harapan Nasabah Terhadap Reliability

\begin{tabular}{|c|c|c|c|c|c|c|c|c|c|c|c|c|}
\hline Tanggapan Nasabah & $\begin{array}{l}\text { San } \\
\text { Pen }\end{array}$ & & & ing & $\begin{array}{l}\mathrm{Cu} \\
\mathrm{Pen}\end{array}$ & & & & & & Jun & lah \\
\hline $\begin{array}{l}\text { Pertanyaan } \\
\text { Kesesuaian dan }\end{array}$ & $f$ & $\%$ & f & $\%$ & $\mathbf{f}$ & $\%$ & $f$ & $\%$ & $f$ & $\%$ & $f$ & $\%$ \\
\hline $\begin{array}{l}\text { ketepatan } \\
\text { pemenuhan janji-janji pegawai } \\
\text { Kêsesuaian'dan ketepatan } \\
\text { pelayanan teller dalam } \\
\text { menyelesaikan transaksi yang } \\
\text { dilakukan oleh nasabah }\end{array}$ & 53 & 44 & 62 & 52 & 5 & 4 & 0 & 0 & 0 & 0 & 120 & 100 \\
\hline $\begin{array}{l}\text { Kesesuaian dan } \\
\text { ketepatan } \\
\text { kemampuan BMT dalam } \\
\text { menjamin keamanan uang } \\
\text { nasabah }\end{array}$ & 88 & 73 & 27 & 23 & 5 & 4 & 0 & 0 & 0 & 0 & 120 & 100 \\
\hline $\begin{array}{l}\text { Ketertiban dalam } \\
\text { pelaksanaan pelayanan }\end{array}$ & 36 & 30 & 64 & 53 & 20 & 17 & 0 & 0 & 0 & 0 & 120 & 100 \\
\hline $\begin{array}{l}\text { Relevansi pelayanan yang } \\
\text { diberikan dengan kebutuhan } \\
\text { nasabah }\end{array}$ & 33 & 28 & 63 & 53 & 24 & 20 & 0 & 0 & 0 & 0 & 120 & 100 \\
\hline $\begin{array}{l}\text { Kesesuaian dan ketepatan } \\
\text { aturan pelayanan }\end{array}$ & 43 & 36 & 58 & 48 & 17 & 14 & 2 & 2 & 0 & 0 & 120 & 100 \\
\hline
\end{tabular}

Sumber : hasil olah data

Pada Tabel 10 menunjukkan bahwa rata-rata tingkat kepuasan nasabah terhadap tampilan fisik gedung BMT di Pamulang sebesar $82,5 \%$ yang termasuk dalam kategori "sangat tinggi". Terlihat bahwa tingkat kepuasan tertinggi dari tampilan fisik gedung BMT di Pamulang yang diperoleh dari nasabah adalah ruang pelayanan. Namun masih ada tingkat kesenjangan total sebesar $17,5 \%$ yang perlu mendapat perhatian. 
Tabel 9. Harapan Nasabah Terhadap Assurance

\begin{tabular}{|c|c|c|c|c|c|c|c|c|c|c|c|c|}
\hline Tanggapan Nasabah & $\begin{array}{l}\text { Sar } \\
\text { Per }\end{array}$ & $\begin{array}{l}\text { sat } \\
\text { ing }\end{array}$ & Pen & & $\begin{array}{l}\text { Cu } \\
\text { Pen }\end{array}$ & $\begin{array}{l}\text { up } \\
\text { ing }\end{array}$ & & $\begin{array}{l}\text { Ing } \\
\text { ing }\end{array}$ & $\begin{array}{l}\mathrm{Sa} \\
\mathrm{Ku} \\
\mathrm{Pe}\end{array}$ & & Jum & lah \\
\hline Pertanyaan & $f$ & $\%$ & $f$ & $\%$ & f & $\%$ & f & $\%$ & f & $\%$ & f & $\%$ \\
\hline $\begin{array}{l}\text { Pengetahuan dan } \\
\text { kemampuan teller dalam } \\
\text { menangani transaksi yang } \\
\text { dilakukan oleh nasabah }\end{array}$ & 84 & 70 & 25 & 21 & 10 & 8 & I & 1 & 0 & 0 & 120 & 100 \\
\hline $\begin{array}{l}\text { Cara teller dalam menjamin } \\
\text { kepastian dan rasa aman } \\
\text { nasabah atas uang yang } \\
\text { disimpan }\end{array}$ & 87 & 73 & 20 & 17 & 13 & II & 0 & 0 & 0 & 0 & 120 & 100 \\
\hline $\begin{array}{l}\text { Keramahan pegawai bank } \\
\text { dalam memberikan }\end{array}$ & 62 & 52 & 55 & 46 & 3 & 3 & 0 & 0 & 0 & 0 & 120 & 100 \\
\hline $\begin{array}{l}\text { Keterampilan pegawai dalam } \\
\text { bekerja dan menyelesaikan } \\
\text { tugas pemberian pelayanan }\end{array}$ & 55 & 46 & 61 & 51 & 4 & 3 & 0 & 0 & 0 & 0 & 120 & 100 \\
\hline $\begin{array}{l}\text { Kejujuran dan } \\
\text { keterbukaan } \\
\text { pimpinan dalam memberi }\end{array}$ & 70 & 58 & 43 & 36 & 7 & 6 & 0 & 0 & 0 & 0 & 120 & 100 \\
\hline
\end{tabular}

Sumber : hasil olah data

Tabel I0. Tingkat Kepuasan Nasabah Terhadap

Tampilan Fisik Gedung BMT

\begin{tabular}{|c|c|c|c|c|c|c|c|}
\hline \multirow[b]{2}{*}{ Pertanyaan } & \multicolumn{2}{|c|}{$\begin{array}{l}\text { Tingkat } \\
\text { Harapan }\end{array}$} & \multicolumn{2}{|c|}{$\begin{array}{l}\text { Tingkat } \\
\text { Kinerja }\end{array}$} & \multicolumn{2}{|c|}{ Kepuasan Pelanggan } & \multirow{2}{*}{$\begin{array}{r}\text { Kategori } \\
\text { Tingkat } \\
\text { Kepuasar }\end{array}$} \\
\hline & $\begin{array}{l}\text { Total } \\
\text { Skor }\end{array}$ & $\begin{array}{l}\text { Rata- } \\
\text { rata } \\
\text { Skor }\end{array}$ & $\begin{array}{l}\text { Total } \\
\text { Skor }\end{array}$ & $\begin{array}{l}\text { Rata- } \\
\text { rata } \\
\text { Skor }\end{array}$ & $\begin{array}{c}\text { Tingkat } \\
\text { Kepuasa } \\
\mathbf{n} \\
\end{array}$ & $\begin{array}{c}\text { Tingkat } \\
\text { Kesenjanga } \\
\mathbf{n} \\
\end{array}$ & \\
\hline Lokasi gedung & 581 & 4.84 & 450 & 3.75 & 77.45 & -22.55 & Tinggi \\
\hline Luas lahan gedung & 522 & 4.35 & 426 & 3.55 & 81.61 & -18.39 & $\begin{array}{l}\text { Sangat } \\
\text { Tinggi }\end{array}$ \\
\hline Ruang pelayanan & 513 & 4.28 & 449 & 3.74 & 87.52 & -12.48 & $\begin{array}{l}\text { Sangat } \\
\text { Tinggi }\end{array}$ \\
\hline $\begin{array}{l}\text { Tempat parkir, mushola, } \\
\text { ruang tunggu, ruang } \\
\text { terbuka dan WC }\end{array}$ & 523 & 4.36 & 430 & 3.58 & 82.22 & -17.78 & $\begin{array}{l}\text { Sangat } \\
\text { Tinggi }\end{array}$ \\
\hline $\begin{array}{l}\text { Kenyamanan serta } \\
\text { kebersihan bank dan }\end{array}$ & 541 & 4.51 & 456 & 3.80 & 84.29 & $-|5.7|$ & $\begin{array}{l}\text { Sangat } \\
\text { Tinggi }\end{array}$ \\
\hline Total & 2680 & 22.33 & 2211 & 18.43 & 82.50 & -17.50 & $\begin{array}{l}\text { Sangat } \\
\text { Tinggi }\end{array}$ \\
\hline
\end{tabular}

Sumber : hasil olah data 
Pada Tabel II menunjukkan bahwa rata-rata tingkat kepuasan nasabah terhadap tampilan fisik perlengkapan BMT di Pamulang sebesar 80,1\% yang termasuk dalam kategori "tinggi". Tampilan fisik perlengkapan sudah dapat dipenuhi oleh kinerja pelayanan BMT dan tingkat kepuasan tertinggi dari tampilan fisik perlengkapan BMT yang diperoleh dari nasabah adalah ketersediaan buku-buku petunjuk pelayanan.

Tabel I I. Tingkat Kepuasan Nasabah Terhadap Tampilan Fisik Perlengkapan BMT

\begin{tabular}{|c|c|c|c|c|c|c|c|}
\hline \multirow[b]{2}{*}{ Pertanyaan } & \multicolumn{2}{|c|}{ Tingkat } & \multicolumn{2}{|c|}{ Tingkat } & \multicolumn{2}{|c|}{ Kepuasan Pelanggan } & \multirow{2}{*}{$\begin{array}{c}\text { Kategori } \\
\text { Tingkat } \\
\text { Kepuasan }\end{array}$} \\
\hline & $\begin{array}{l}\text { Total } \\
\text { Skor }\end{array}$ & $\begin{array}{l}\text { Rata- } \\
\text { rata } \\
\text { clene }\end{array}$ & $\begin{array}{l}\text { Total } \\
\text { Skor }\end{array}$ & $\begin{array}{l}\text { Rata- } \\
\text { Rata } \\
\text { Clenr }\end{array}$ & $\begin{array}{c}\text { Tingkat } \\
\text { Kepuasa } \\
\text { n }\end{array}$ & $\begin{array}{c}\text { Tingkat } \\
\text { Kesenjanga }\end{array}$ & \\
\hline $\begin{array}{l}\text { Kelengkapan sarana } \\
\text { pelayanan }\end{array}$ & 537 & 4.48 & 420 & 3.50 & 78.21 & -21.79 & Tinggi \\
\hline $\begin{array}{l}\text { Ketersediaan buku- buku } \\
\text { petunjuk pelayanan }\end{array}$ & 499 & 4.16 & 408 & 3.40 & 81.76 & -18.24 & $\begin{array}{l}\text { Sangat } \\
\text { Tinggi }\end{array}$ \\
\hline $\begin{array}{l}\text { Kelengkapan sarana } \\
\text { administrasi }\end{array}$ & 522 & 4.35 & 420 & 3.50 & 80.46 & -19.54 & Tinggi \\
\hline Total & 1558 & 12.98 & 1248 & 10.40 & 80.10 & -19.90 & Tinggi \\
\hline
\end{tabular}

Sumber : hasil olah data

Tabel I 2. Tingkat Kepuasan Nasabah Terhadap Tampilan Fisik SDM BMT

\begin{tabular}{|c|c|c|c|c|c|c|c|}
\hline \multirow[b]{2}{*}{ Pertanyaan } & \multicolumn{2}{|c|}{$\begin{array}{l}\text { Tingkat } \\
\text { Harapan }\end{array}$} & \multicolumn{2}{|c|}{$\begin{array}{l}\text { Tingkat } \\
\text { Kinerja }\end{array}$} & \multicolumn{2}{|c|}{ Kepuasan Pelanggan } & \multirow{2}{*}{$\begin{array}{c}\text { Kategori } \\
\text { Tingkat } \\
\text { Kepuasan }\end{array}$} \\
\hline & $\begin{array}{l}\text { Total } \\
\text { Skor }\end{array}$ & $\begin{array}{l}\text { Rata- } \\
\text { rata } \\
\text { Skor }\end{array}$ & $\begin{array}{l}\text { Total } \\
\text { Skor }\end{array}$ & $\begin{array}{l}\text { Rata } \\
\text { Rata } \\
\text { Skor }\end{array}$ & $\begin{array}{c}\text { Tingkat } \\
\text { Kepuasa } \\
\text { n }\end{array}$ & $\begin{array}{c}\text { Tingkat } \\
\text { Kesenjanga } \\
\mathbf{n}\end{array}$ & \\
\hline $\begin{array}{l}\text { Tingkat kesiapan pegawai } \\
\text { melayani nasabah }\end{array}$ & 560 & 4.67 & 447 & 3.73 & 79.82 & -20.18 & Tinggi \\
\hline $\begin{array}{l}\text { Penampilan dan kerapihan } \\
\text { front office }\end{array}$ & 519 & 4.33 & 476 & 3.97 & 1.71 & -8.29 & $\begin{array}{l}\text { Sangat } \\
\text { Tinggi }\end{array}$ \\
\hline Total & 1079 & 8.99 & 923 & 7.69 & 85.54 & -14.46 & $\begin{array}{l}\text { Sangat } \\
\text { Tinggi }\end{array}$ \\
\hline
\end{tabular}

Sumber : hasil olah data

Pada Tabel 12 dapat ditunjukkan bahwa rata-rata tingkat kepuasan nasabah terhadap tampilan fisik SDM BMT di Pamulang sebesar 85,54\% yang termasuk dalam kategori "sangat tinggi" artinya aspek kualitas tangible, khususnya tampilan fisik SDM sudah dapat dipenuhi oleh kinerja pelayanan BMT di Pamulang. 
Tabel 13. Tingkat Kepuasan Nasabah Terhadap Emphaty Pada BMT

\begin{tabular}{|c|c|c|c|c|c|c|c|}
\hline \multirow[b]{2}{*}{ Pertanyaan } & \multicolumn{2}{|c|}{$\begin{array}{l}\text { Tingkat } \\
\text { Harapan }\end{array}$} & \multicolumn{2}{|c|}{$\begin{array}{l}\text { Tingkat } \\
\text { Kinerja }\end{array}$} & \multicolumn{2}{|c|}{$\begin{array}{l}\text { Kepuasan } \\
\text { Pelanggan }\end{array}$} & \multirow{2}{*}{$\begin{array}{c}\text { Kategori } \\
\text { Tingkat } \\
\text { Kepuasan }\end{array}$} \\
\hline & $\begin{array}{l}\text { Total } \\
\text { Skor }\end{array}$ & $\begin{array}{c}\text { Rata- } \\
\text { rata } \\
\text { Skor }\end{array}$ & $\begin{array}{l}\text { Total } \\
\text { Skor }\end{array}$ & $\begin{array}{l}\text { Rata- } \\
\text { Rata } \\
\text { Skor }\end{array}$ & $\begin{array}{c}\text { Tingkat } \\
\text { Kepuasa I } \\
\mathbf{n}\end{array}$ & $\begin{array}{l}\text { Tingkat } \\
\text { Kesenjang } \\
\text { an }\end{array}$ & \\
\hline $\begin{array}{l}\text { Kemudahan } \\
\text { menghubungi pegawai } \\
\text { vang hertugas }\end{array}$ & 534 & 4.45 & 427 & 3.56 & 79.96 & -20.04 & Tinggi \\
\hline $\begin{array}{l}\text { Kemudahan menemui } \\
\text { pempinan \& staf }\end{array}$ & 517 & 4.31 & 416 & 3.47 & 80.46 & -19.54 & Tinggi \\
\hline $\begin{array}{l}\text { Kesungguhan teller dlm } \\
\text { memberi perhatian secara }\end{array}$ & 523 & 4.36 & 451 & 3.76 & 86.23 & -13.77 & $\begin{array}{l}\text { Sangat } \\
\text { Tinggi }\end{array}$ \\
\hline $\begin{array}{l}\text { Kemampuan pegawai utk } \\
\text { memahami stp kebutuhan }\end{array}$ & 520 & 4.33 & 451 & 3.76 & 86.73 & -13.27 & $\begin{array}{l}\text { Sangat } \\
\text { Tinggi }\end{array}$ \\
\hline $\begin{array}{l}\text { Kemampuan pegawai dalam } \\
\text { mengenal setiap nasabahnya }\end{array}$ & 497 & 4.14 & 423 & 3.53 & 85.11 & -14.89 & $\begin{array}{l}\text { Sangat } \\
\text { Tinggi }\end{array}$ \\
\hline Total & 2591 & 21.59 & 2168 & 18.07 & 83.67 & -16.33 & $\begin{array}{l}\text { Sangat } \\
\text { Tinggi }\end{array}$ \\
\hline
\end{tabular}

Sumber : hasil olah data, 2013

Pada Tabel 13 menunjukkan bahwa rata-rata tingkat kepuasan nasabah terhadap dimensi kualitas pelayanan emphaty pada BMT di Pamulang sebesar $83,67 \%$ yang termasuk dalam kategori "sangat tinggi". Fakta ini menunjukkan bahwa aspek kualitas emphaty sudah dapat dipenuhi oleh kinerja pelayanan BMT di Pamulang. Namun masih ada tingkat kesenjangan total sebesar $16,33 \%$.

Tabel I4. Tingkat Kepuasan Nasabah Terhadap Responsiveness Pada BMT di Pamulang

\begin{tabular}{|c|c|c|c|c|c|c|c|}
\hline \multirow[b]{2}{*}{ Pertanyaan } & \multicolumn{2}{|c|}{$\begin{array}{l}\text { Tingkat } \\
\text { Harapan }\end{array}$} & \multicolumn{2}{|c|}{$\begin{array}{l}\text { Tingkat } \\
\text { Kinerja }\end{array}$} & \multicolumn{2}{|c|}{ Kepuasan Pelanggan } & \multirow[b]{2}{*}{$\begin{array}{c}\text { Kategori } \\
\text { Tingkat } \\
\text { Kepuasan }\end{array}$} \\
\hline & $\begin{array}{l}\text { Total } \\
\text { Skor }\end{array}$ & $\begin{array}{l}\text { Rata- } \\
\text { rata } \\
\text { Skor }\end{array}$ & $\begin{array}{l}\text { Total } \\
\text { Skor }\end{array}$ & $\begin{array}{l}\text { Rata- } \\
\text { rata } \\
\text { Skor }\end{array}$ & $\begin{array}{c}\text { Tingkat } \\
\text { Kepuasa } \\
\mathbf{n}\end{array}$ & $\begin{array}{c}\text { Tingkat } \\
\text { Kesenjanga } \\
\mathbf{n}\end{array}$ & \\
\hline $\begin{array}{l}\text { Kesediaan dan kesiapan } \\
\text { pegawai untuk melayani } \\
\text { nasabah }\end{array}$ & 557 & 4.64 & 428 & 3.57 & 76.84 & -23.16 & Tinggi \\
\hline $\begin{array}{l}\text { Kecepatan dan ketepatan } \\
\text { pegawai dalam melayani } \\
\text { nasabah }\end{array}$ & 530 & 4.42 & 430 & 3.58 & 81.13 & -18.87 & $\begin{array}{l}\text { Sangat } \\
\text { Tinggi }\end{array}$ \\
\hline
\end{tabular}


Kecepatan dan ketepatan pegawai dalam mengirim slip transaksi

80.30

$-19.70$

Tinggi

Kesediaan dan ketanggapan customer sevice officer 526

4.38

4.38

413

3.44

78.52

$-21.48$

Tinggi

dalam memberikan pelayanan

Kesediaan dan kecepatan

pimpinan dalam

488

4.07

$439 \quad 3.66$

89.96

$-10.04 \quad$ Sangat

menangani

$$
\text { Total }
$$

2639

21.99

2142

17.85

81.17

$-18.83$

Tinggi

Sumber : hasil olah data

Pada Tabel 14 menunjukkan bahwa rata-rata tingkat kepuasan nasabah terhadap dimensi kualitas pelayanan Responsiveness pada BMT di Pamulang sebesar 8I,17\% yang termasuk dalam kategori "sangat tinggi".

Tabel I5. Tingkat Kepuasan Nasabah Terhadap Reliability Pada BMT

\begin{tabular}{|c|c|c|c|c|c|c|c|}
\hline \multirow[b]{2}{*}{ Pertanyaan } & \multicolumn{2}{|c|}{ Tingkat Harapan } & \multicolumn{2}{|c|}{$\begin{array}{l}\text { Tingkat } \\
\text { Kinerja }\end{array}$} & \multicolumn{2}{|c|}{ Kepuasan Pelanggan } & \multirow{2}{*}{$\begin{array}{c}\text { Kategori } \\
\text { Tingkat } \\
\text { Kepuasa } \\
\text { n }\end{array}$} \\
\hline & $\begin{array}{l}\text { Total } \\
\text { Skor }\end{array}$ & $\begin{array}{l}\text { Rata- } \\
\text { rata } \\
\text { Skor }\end{array}$ & $\begin{array}{l}\text { Total } \\
\text { Skor }\end{array}$ & $\begin{array}{l}\text { Rata- } \\
\text { Rat a } \\
\text { Skor }\end{array}$ & $\begin{array}{l}\text { Tingkat } \\
\text { Kepuasa }\end{array}$ & $\begin{array}{l}\text { Tingkat } \\
\text { Kesenjanga }\end{array}$ & \\
\hline $\begin{array}{l}\text { Kesesuaian dan ketepatan } \\
\text { pemenuhan janji- janji } \\
\text { pegawai terhadap nasabah }\end{array}$ & 528 & 4.40 & 422 & 3.52 & 79.92 & -20.08 & Tinggi \\
\hline $\begin{array}{l}\text { Kesesuaian dan ketepatan } \\
\text { pelayanan teller dalam } \\
\text { menyelesaiakan transaksi }\end{array}$ & 529 & $4.4 I$ & 433 & 3.61 & 81.85 & -18.15 & $\begin{array}{l}\text { Sangat } \\
\text { Tinggi }\end{array}$ \\
\hline $\begin{array}{l}\text { Kesesuaian dan ketepatan } \\
\text { kemampuan BMT dlm } \\
\text { menjamin keamanan uang }\end{array}$ & 563 & 4.69 & 429 & 3.58 & 76.20 & -23.80 & Tinggi \\
\hline $\begin{array}{l}\text { Ketertiban dalam pelaksanaan } \\
\text { pelayanan }\end{array}$ & 496 & 4.13 & 420 & 3.50 & 84.68 & -15.32 & $\begin{array}{l}\text { Sangat } \\
\text { Tinggi }\end{array}$ \\
\hline $\begin{array}{l}\text { Relevansi pelayanan yang } \\
\text { diberikan dengan kebutuhan } \\
\text { nasabah }\end{array}$ & 489 & 4.08 & 424 & 3.53 & 86.71 & -13.29 & $\begin{array}{l}\text { Sangat } \\
\text { Tinggi }\end{array}$ \\
\hline $\begin{array}{l}\text { Kesesuaian dan ketepatan } \\
\text { aturan pelayanan }\end{array}$ & 502 & 4.18 & 424 & 3.53 & 84.46 & -15.54 & $\begin{array}{l}\text { Sangat } \\
\text { Tinggi }\end{array}$ \\
\hline Total & 3107 & 25.89 & 2552 & 21.27 & 82.14 & -17.86 & $\begin{array}{l}\text { Sangat } \\
\text { Tinggi }\end{array}$ \\
\hline
\end{tabular}

Pada Tabel 15 menunjukkan bahwa rata-rata tingkat kepuasan nasabah terhadap dimensi kualitas pelayanan reliability pada BMT sebesar $82,14 \%$ yang termasuk dalam 
kategori "sangat tinggi". Aspek kualitas reliability sudah dapat dipenuhi oleh kinerja pelayanan BMT di Pamulang.

Tabel 16. Tingkat Kepuasan Nasabah Terhadap Assurance Pada BMT

\begin{tabular}{|c|c|c|c|c|c|c|c|}
\hline \multirow[b]{2}{*}{ Pertanyaan } & \multicolumn{2}{|c|}{$\begin{array}{c}\text { Tingkat } \\
\text { Harapan }\end{array}$} & \multicolumn{2}{|c|}{$\begin{array}{l}\text { Tingkat } \\
\text { Kinerja }\end{array}$} & \multicolumn{2}{|c|}{ Kepuasan Pelanggan } & \multirow{2}{*}{$\begin{array}{l}\text { Kategori } \\
\text { Tingkat } \\
\text { Kepuasan }\end{array}$} \\
\hline & $\begin{array}{l}\text { Total } \\
\text { Skor }\end{array}$ & $\begin{array}{l}\text { Rata- } \\
\text { Rata } \\
\text { Skor }\end{array}$ & $\begin{array}{l}\text { Total } \\
\text { Skor }\end{array}$ & $\begin{array}{l}\text { Rata- } \\
\text { Rata } \\
\text { Skor }\end{array}$ & $\begin{array}{c}\text { Tingkat } \\
\text { Kepuasa } \\
\mathbf{n}\end{array}$ & $\begin{array}{c}\text { Tingkat } \\
\text { Kesenjanga } \\
\mathbf{n}\end{array}$ & \\
\hline $\begin{array}{l}\text { Pengetahuan dan kemampuan } \\
\text { teller dalam menangani }\end{array}$ & 552 & 4.60 & 465 & 3.88 & 84.24 & -15.76 & $\begin{array}{l}\text { Sangat } \\
\text { Tinggi }\end{array}$ \\
\hline $\begin{array}{l}\text { Cara teller dalam menjamin } \\
\text { kepastian dan rasa aman } \\
\text { nasabah atas uang yang }\end{array}$ & 554 & 4.62 & 488 & 4.07 & 88.09 & $-\mid 1.91$ & $\begin{array}{l}\text { Sangat } \\
\text { Tinggi }\end{array}$ \\
\hline $\begin{array}{l}\text { Keramahan pegawai bank dalam } \\
\text { memberikan pelayanan }\end{array}$ & 539 & 4.49 & 492 & 4.10 & 91.28 & -8.72 & $\begin{array}{l}\text { Sangat } \\
\text { Tinggi }\end{array}$ \\
\hline $\begin{array}{l}\text { Keterampilan pegawai } \\
\text { dalam bekerja dan } \\
\text { menyelesaikan tugas }\end{array}$ & 531 & 4.43 & 447 & 3.73 & 84.18 & -15.82 & $\begin{array}{l}\text { Sangat } \\
\text { Tinggi }\end{array}$ \\
\hline $\begin{array}{l}\text { Kejujuran dan keterbukaan } \\
\text { pimpinan dalam memberi } \\
\text { informasi dan pelayanan }\end{array}$ & 543 & 4.53 & 466 & 3.88 & 85.82 & -14.18 & $\begin{array}{l}\text { Sangat } \\
\text { Tinggi }\end{array}$ \\
\hline Total & 2719 & 22.66 & 2358 & 19.65 & 86.72 & -13.28 & $\begin{array}{l}\text { Sangat } \\
\text { Tinggi }\end{array}$ \\
\hline
\end{tabular}

Sumber : hasil olah data

Pada Tabel 16 menunjukkan bahwa rata-rata tingkat kepuasan nasabah terhadap dimensi kualitas pelayanan assurance pada BMT Di Pamulang sebesar 86,72\% yang termasuk dalam kategori "sangat tinggi". Fakta ini menunjukkan tingkat kepuasan pelanggan secara umum dilihat dari aspek kualitas assurance sudah dapat dipenuhi oleh kinerja pelayanan BMT di Pamulang.

\section{Pembahasan}

Nasabah yang memperoleh kepuasan dalam pelayanan merupakan modal dasar bagi BMT dalam membentuk loyalitas pelanggan. Menurut Tjiptono (1996) setiap perusahaan yang memperhatikan kepuasan pelanggan akan memperoleh beberapa manfaat pokok yaitu reputasi perusahaan yang makin positif di mata masyarakat dan pelanggan, dapat mendorong terciptanya loyalitas pelanggan, memungkinkan terciptanya rekomendasi dari mulut ke mulut yang menguntungkan bagi perusahaan, meningkatkan keuntungan, makin harmonisnya hubungan 
perusahaan dan pelanggannya serta mendorong setiap anggota organisasi untuk bekerj a sesuai dengan tuj uannya.

Memiliki pelanggan yang loyal adalah tujuan akhir dari semua perusahaan. Tetapi kebanyakan dari perusahaan atau produsen tidak mengetahui bahwa loyalitas pelanggan dapat dibentuk melalui beberapa tahapan. Mulai dari mencari calon pelanggan potensial sampai dengan advocate customer yang akan membawa keuntungan bagi perusahaan.

Hasil scoring menunjukkan bahwa loyalitas nasabah pada BMT di Pamulang sebesar I.382 yang termasuk dalam kategori "sedang". Fakta ini memberikan indikasi bahwa loyalitas nasabah pada BMT di Pamulang masih perlu untuk ditingkatkan agar dapat mencapai kategori tinggi atau sangat tinggi. Hal ini didukung oleh jawaban responden mengenai frekuensi pemanfaatan pelayanan, kesediaan nasabah melakukan pembelian di luar lini pelayanan, melakukan penolakan terhadap pelayanan yang diberikan oleh pesaing BMT, dan frekuensi memberi saran kepada nasabah lain untuk menggunakan pelayanan BMT di Pamulang sebagai berikut: (a) Frekuensi Pemanfaatan Pelayanan Pada BMT di Pamulang, responden memberikan jawaban "cukup sering" dalam memanfaatkan pelayanan pada BMT di Pamulang. Hal ini menunjukkan bahwa nasabah BMT telah melakukan pemanfaatan pelayanan ulang terhadap pelayanan yang ditawarkan. Fakta ini sejalan dengan apa yang diungkapkan Griffin (2005) yang mengatakan bahwa pelanggan yang loyal adalah yang melakukan pembelian ulang (repeat purchase). Namun masih ada sekitar $22 \%$ responden yang menyatakan "sangat jarang" memanfaatkan pelayanan yang ditawarkan oleh BMT yang disebabkan karena pelayanan yang diberikan masih relatif lambat, fasilitas online sistem masih relatif terbatas, dan adanya BMT pesaing yang mampu memberikan pelayanan cepat dan berkualitas bagus; (b) Frekuensi Nasabah Memanfaatkan Pelayanan di Luar Lini Pelayanan BMT, ditunjukkan bahwa sebagian besar responden memberikan jawaban "cukup bersedia" dalam memanfaatkan pelayanan di luar lini pelayanan yang ditawarkan oleh BMT di Pamulang. Fakta ini memberi gambaran bahwa responden masih bersedia menggunakan pelayanan di luar lini pelayanan yang ditawarkan. Namun masih ada sekitar 9\% responden yang menyatakan "tidak bersedia" dan $3 \%$ yang menyatakan "sangat tidak bersedia" memanfaatkan pelayanan di luar lini pelayanan yang ditawarkan, yang disebabkan karena pelayanan lain-lain yang 
ditawarkan masih relatif mahal biayanya jika dibandingkan dengan pelayanan yang ditawarkan oleh BMT pesaing; (c) Kesediaan Nasabah Melakukan Penolakan Terhadap Pelayanan yang diberikan Pesaing BMT, sebagian besar nasabah memberikan jawaban "cukup bersedia" untuk melakukan penolakan terhadap pelayanan yang ditawarkan oleh pesaing BMT di Pamulang. Fakta ini memberi gambaran bahwa nasabah relatif melakukan penolakan terhadap pelayanan yang diberikan oleh pesaing BMT. Kenyataan ini sesuai dengan pendapat Griffin (2005) yang mengatakan bahwa pelanggan yang loyal adalah pelanggan yang bersedia menolak layanan yang diberikan oleh pesaing; (d) Frekuensi Memberi Saran Kepada Nasabah Lain Untuk Menggunakan Pelayanan BMT, dapat ditunjukkan bahwa sebagian besar nasabah memberikan jawaban "sering" untuk memberikan saran kepada nasabah lain untuk menggunakan pelayanan dari BMT di Pamulang. Fakta ini memberi gambaran bahwa nasabah relatif sering dalam memberikan saran untuk menggunakan pelayanan BMT. Namun masih ada sekitar $23 \%$ responden yang menyatakan "sangat jarang" untuk memberikan saran untuk menggunakan pelayanan BMT di Pamulang.

Hasil analisis regresi menunjukkan bahwa kualitas pelayanan yang terdiri dari dimensi Tangible, Emphaty, Responsiveness, Reliability dan Assurance berpengaruh signifikan terhadap loyalitas nasabah pada BMT di Pamulang ditunjukkan dengan nilai $R$ square sebesar 15,7\%. Sedangkan pengaruh faktor error atau pengaruh variabelvariabel lain diluar model yang cukup besar yaitu sebesar $84,3 \%$. Sedangkan pengaruh secara parsial, variabel responsiveness dan assurance yang berpengaruh positif signifikan masing-masing sebesar $21.2 \%$ dan $12,1 \%$.

Hasil analisis deskriptif menunjukkan bahwa (a) kualitas pelayanan BMT di Pamulang baik secara total maupun per dimensi kualitas pelayanan berada dalam kategori 'tinggi' dan (b) loyalitas nasabah pada BMT di Pamulang berada dalam kategori 'sedang'. Upaya meningkatkan loyalitas nasabah dengan memanfaatkan pelayanan di BMT di Pamulang, pimpinan dan pihak terkait perlu memperhatikan kualitas pelayanan yang diberikan kepada nasabah karena kualitas pelayanan berpengaruh positif dan nyata terhadap loyalitas nasabah. Loyalitas nasabah juga dapat menjadi sarana promosi bagi BMT di Pamulang melalui pemahaman sikap dan perilaku nasabah sebagai pelanggan jasa. 


\section{PUSTAKA ACUAN}

Arikunto, Suharsini. 1996. Prosedur Penelitian Suatu Pendekatan Praktek. Edisi Revisi. Reineka Cipta. Jakarta.

Griffin, Jill. 1996. Customer Loyalty, published by Jossey-Bass.

Griffin, Jill. 2005. Customer loyalty : menumbuhkan dan mempertahankan kesetiaan pelanggan, Jakarta: erlangga

Oliver, L. , et al. 1997. Customer Delight: Foundations, Findings, and Managerial Insight. Journal of Retailing, 73 (3): 3II-336.

Tjiptono, Fandy .1996. Manajemen Jasa. Penerbit Andi. Yogyakarta

Tjiptono, Fandy \& Gregorius Chandra. 2005. Service, Quality \& Satisfaction., Yogyakarta:Andi

Umar, Husein. 2000. Riset Pemasaran dan Perilaku Konsumen. PT. Gramedia Pustaka Utama, Jakarta.

Zeithaml, Valarie A, Leonard. Berry, And A. Parasuraman dan Berry. 1990. Delivering Quality Service Balancing Customer Perseptions and Expectation. The Free Press. New York.

Zeithaml, Berry and Parasuraman, "The Behavioral Consequences of Service Quality," Journal of Marketing, April 1996, pp. 31-46. 